Journal of Engineering and Applied Sciences 15 (1): 206-212, 2020

ISSN: 1816-949X

(C) Medwell Journals, 2020

\title{
Environmental Effects of Poor Wastes Disposal on Stream Water Quality: A Case Study of Eha-Alumona in Nsukka East LGA of Enugu State, Nigeria
}

\author{
${ }^{1}$ C. N. Mama, ${ }^{1}$ C.C. Nnaji, ${ }^{2}$ I.P. Obe, ${ }^{1}$ P.C. Ihuagu, ${ }^{1}$ I.A. Yakubu, \\ ${ }^{3}$ F.O. Okechukwu and ${ }^{4}$ C.K. Ezugwu \\ ${ }^{1}$ Department of Civil Engineering, \\ ${ }^{2}$ Department of Industrial Technical Education, \\ ${ }^{3}$ Department of Home Science and Management, \\ ${ }^{4}$ Department of Geology, University of Nigeria, Nsukka, Nigeria
}

\begin{abstract}
This research focused on the environmental effects of poor wastes disposal on the stream water quality in Eha-Alumona Area in Nsukka LGA of Enugu State. Okpe stream was chosen among other streams for this study. The objectives were to: identify and describe the stream water resources in the study area, examine the composition of solid wastes and their disposal methods, assess the effects of waste dumps on the stream water quality, examine the health implications of the observed trend; above all, to suggest effective management strategies for managing solid wastes in the study area. Laboratory analysis of physical, chemical and biological quality of stream water samples from two different sample locations were carried out by dipping one litre of clean plastic container into the stream for about 1.2 and $2.5 \mathrm{~m}$ away from where most of the refuses are disposed and these are labeled as sample stations A and B, respectively. The parameters considered using recognized standard test procedures were: colour, $\mathrm{pH}$, total dissolved solids, total suspended solids, chemical oxygen demand, biochemical oxygen demand, coliform, nitrates, chloride, calcium, magnesium and dissolved oxygen. Relevant data were collected from field observation and the use of questionnaires. The results revealed that the quality of surface water in Eha-Alumona has been affected by indiscriminate dumping of waste. The stream water was found to be unsuitable for human consumption when compared with World Health Organization water quality standard for drinking and domestic use. Re-orientation of the people, sorting of waste before disposal, reduced use of contaminants by the people and treatment of contaminated surface water before use were recommended as measures to control the menace.
\end{abstract}

Key words: Environmental, poor, waste disposal, stream, water quality, contaminated

\section{INTRODUCTION}

Water is used for many domestic purposes like drinking, food preparation, cooking, bathing, washing (cloths and utensils) and house cleaning. Water is fundamental to all life on Earth and as Arvill (1967) claimed, "life originated from water". Generally, especially in the developing countries, lakes, streams and rivers are the veritable sources of water supply to the cities and rural communities. Currently there is a global shortage of potable water, hence; the water question is being examined by various researchers and agencies from the point of view of sources, demand, supply, distribution, utilization and quality. According to Akaninwor et al. (2007), pollution of fresh water bodies such as rivers, streams, lakes and ponds is mostly experienced as a result of industrial discharge, municipal waste disposal and surface run off. Indiscriminate and uncontrolled discharge of waste into rivers impact negatively on river ecosystems and human health (Odokuma and
Okpokwasili, 2004; Kinnersley, 1994; Benka-Coker and Ojior, 1995; Nwachukwu and Otokunefor, 2003; Ubalua and Ezeronye, 2005). An acceptable water quality is crucial in order that man can benefit from rivers through a series of uses (Sweeting, 1994). Water quality deterioration has continued to place great pressure on global water resources. A very large percentage of the world's population is under water stress and therefore, it is a resource worthy of conservation and protection (Adejemilua, 2007; Singhal and Pandey, 2001). It is well known that safe drinking water supply and basic sanitation are vital to human health and efficiency. According to the WHO., (2005), about 30,000 people die every day globally due to unsafe water consumption and insufficient commutation. About 10 million women spend half their day walking in the hot sun, to carry home polluted water which poisons them and their families. In the same vein, WHO (2005) affirmed that more than 1 billion people lack access to safe drinking water and this is the major cause of diseases and death in the world. 
Egwari and Aboaba (2002), also noted that about 2.6 billion people in the world lack access to improved sanitation. At any given time about half of the world's hospital beds are occupied by patients suffering from water-related diseases. Every $15 \mathrm{sec}$ a child dies from water related diseases and children under the age 5 . Disease like acute gastroenteritis and diarrhoea often require hospitalization. About 1.8 million children die each year of diarrhoea; that is more deaths now occur through water-related diseases than through war.

In Nigeria, there is very high incidence of childhood diarrhoea. This is largely due to the unavailability of potable water, especially in rural communities where mothers often obtain water from contaminated streams. Moreso, the rapid growth of population in the rural areas including my study area (Eha-Alumona) has created waste management problems and because of this, the available streams now serve as receptacles for many of the generated wastes. Indiscriminate disposal of wastes into river or along its channels is now a common and routine practice in the area. This development generates concerns about the ecological integrity of the stream as well as the quality of the stream water. Some of these wastes are dumped directly into the river. Hence, the aim of this research is to ascertain: the environmental effects of poor wastes disposal on the stream water quality in Eha-Alumona Area in Nsukka LGA of Enugu State.

\section{MATERIALS AND METHODS}

Geology of the study area: The case study for this research as already stated is Eha-Alumona which is a town in Nsukka Local Government Area in Southeast Nigeria in Enugu State (Fig. 1). Oral history has it that Nsukka has very close ties with three other neighboring towns: Obukpa, Okpuje and Eha which are said to have common ancestral origins while the last Eha is a patrilineal brother of the other three relations. The town is therefore, called Eha-Alumona.

Eha-Alumona community in Nsukka Local Government Area of Enugu State is one of such priceless community blessed with mineral resources which if well harnessed, could contribute meaningfully to the development of Enugu State and the country at large. Sprawled across 5000 ha of land and an estimated 3000 residents. Eha-Alumona is a community flowing with the proverbial milk and honey. The community which is surrounded by neighbouring towns like: Mbu, Neke, Ikem in Isi-Uzo local government area of the state is endowed with both human and mineral resources which earn it the bragging right of being "the food basket of Enugu State”.

The community is one of the largest communities in Nsukka LGA. Resources buried under its ground include: crude oil, cola, clay and limestone. It also has palm oil,

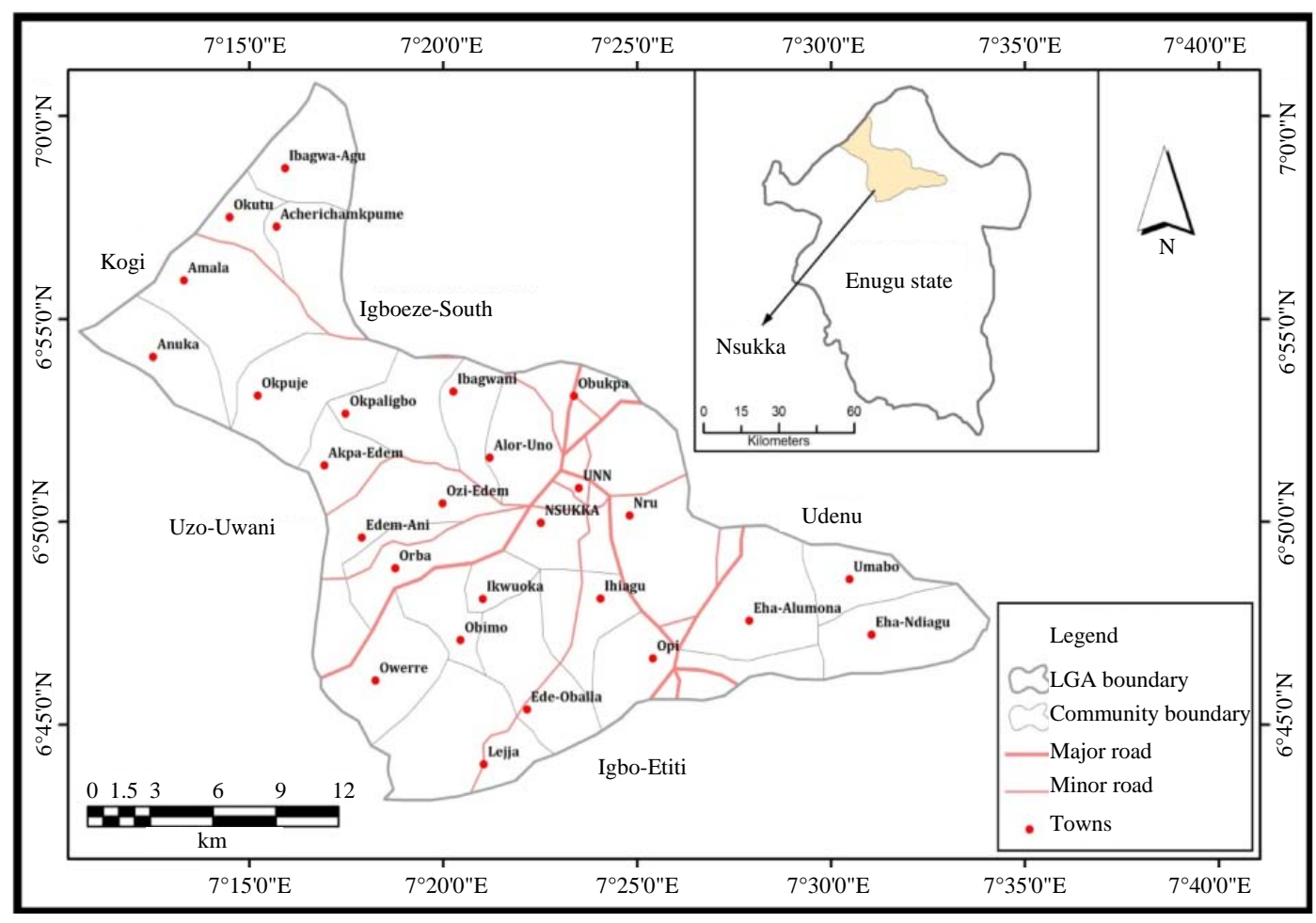

Fig. 1: Map of Nsukka local government area showing Eha-Alumona town 


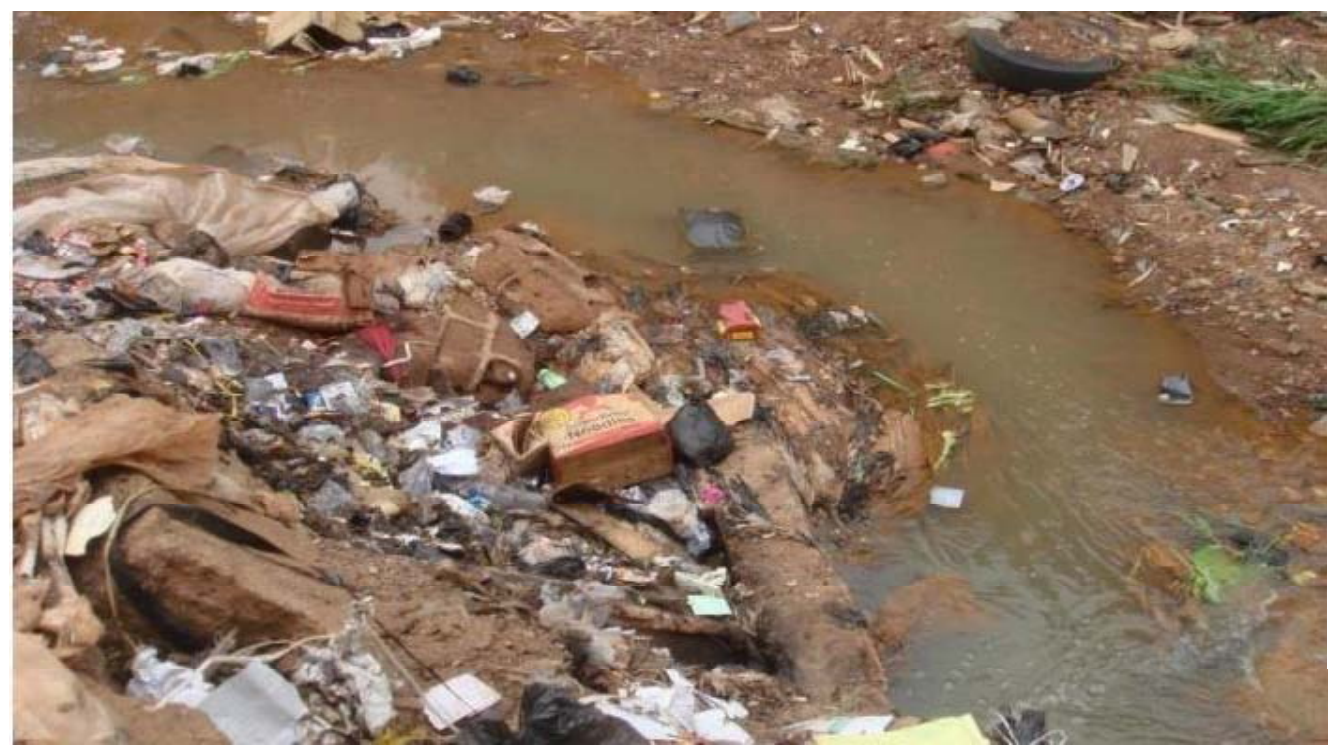

Fig. 2: The Okpe stream being turned into refuse dump

honey, cashew plantation which spanned over 50 ha of land, plantain and banana plantations, yam, garri, orange and the likes. Such avalanches of resources at the community's disposal are enough to boost the state's economy by $25 \%$. For instance, the large deposit of crude oil estimated to last for 50 years as it was gathered has about $30 \%$ petrol and $70 \%$ natural gas. With these mineral and agricultural resources, Eha-Alumona is unarguably a custodian of economic solution to Enugu State and Nigeria at large.

Eha-Alumona is surrounded with many streams and rivers such as Orikolobo stream, Okpe stream, Elufi stream Amanyi river, Ekpuruhe stream, Ezeborulo stream and Okpe river. The stream used in this study is the Okpe stream. This stream has its source from the tributaries of Amanyi river and flows Eastwardly. It is a perennial river and the inhabitants of Eha-Alumona and environs attach a cultural value to it and describe it as being the fathers of all the surface waters in the area.

Uses of stream (Okpe stream) water resources in the study: The rivers and the springs are water sources from which the people in the study area access useable water for various purposes. The water accessed is used primarily for cooking, drinking, laundry and for practicing micro agricultural activities. Unfortunately, during rainy season, observations revealed that majority of the people dump their refuse into run off channels linked directly to the stream while others dump into the rivers and streams during both dry and raining season (Fig. 2).

Questionnaires were distributed to the community to know the reasons behind the refuse disposal in and around Okpe stream. The research work uses two different sample to analyze the quality of the surface water in Eha-Alumona as affected by indiscriminate dumping of refuse. The sampled station A which was collected from a distance of $1.2 \mathrm{~m}$ was compared with the sampled stations B which was also collected $2.5 \mathrm{~m}$ away from the refuse dump; to know the difference in water qualities between the two and to compare them with WHO drinking water standard.

Laboratory analyses were carried out on the samples. AOAC (2005) procedures were used to determine the following: colour, $\mathrm{pH}$, total dissolve solid, total suspended solid, coliform, chemical oxygen demand, biochemical oxygen demand, total hardness, nitrate, chloride, calcium, magnesium and dissolved oxygen.

\section{RESULTS AND DISCUSSION}

Apart from streams and rivers, other sources of water in the area include taps and boreholes which are found in few compounds. This is because of inadequate capital to put these facilities in locations where they are required. The hand dug wells also are found in almost every compound in Eha-Alumona and environs. This is because the cost required to put them in place is relatively low compared to the cost of developing either the water taps or the boreholes.

Again, during dry season when some wells dried up, people buy water from tankers or from the few areas with boreholes. The many low-income earners who cannot afford to buy water, get it from the nearest river which flows at all seasons. Table 1 provides more information on the other existing sources of water supply in the area. Supply identified or available in the study area includes: borehole, streams/rivers, hand dug well, tankers and tap water. As shown in Table 1, the major source of water for domestic purposes in the study area is hand dug wells which were observed almost in all the compounds in the 
J. Eng. Applied Sci., 15 (1): 206-212, 2020

Table 1: Other sources of water for domestic purposes in the study area

\begin{tabular}{lcc} 
Water sources & No. of responses & Percentages \\
\hline Boreholes & 40 & 5.86 \\
Rivers/streams & 290 & 42.46 \\
Hand dug wells & 300 & 43.93 \\
From tankers & 25 & 3.66 \\
Tap waters & 28 & 4.10 \\
Total & 683 & 1.00 \\
\hline
\end{tabular}

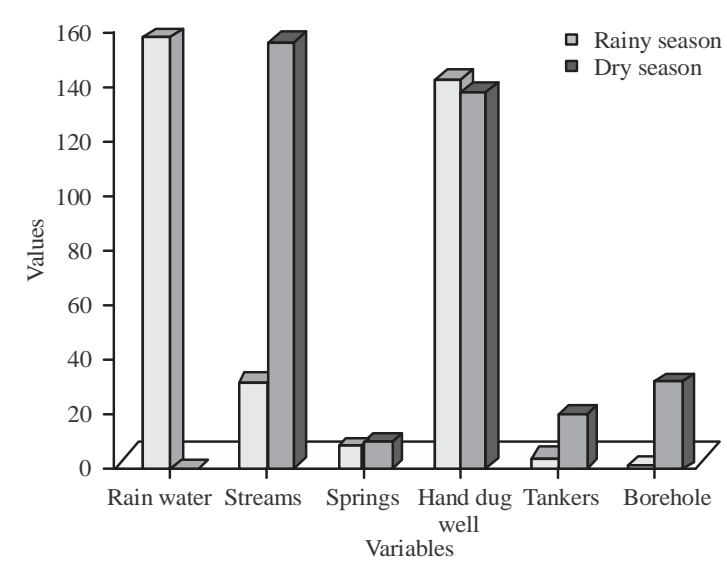

Fig. 3: Seasonal variation in the sources of water in the study area

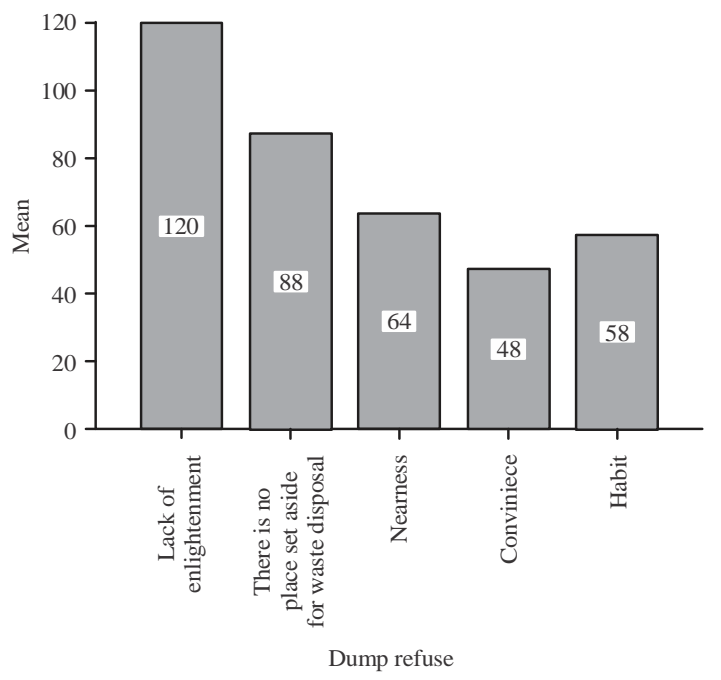

Fig. 4: Respondents identified reasons why people dump refuse into stream

study area as a result of the geology of the area. This is followed by rivers/streams on which $42.46 \%$ of the people depend. Again, 5.86\% of the respondents indicated that boreholes are their major source of water for domestic purposes while $4.0 \%$ indicated tap water. The source of water $(3.66 \%)$ as shown by the respondents is from tankers/commercial services.

Seasonal variation in the sources of water in the study area: Figure 3-5 shows the result from questionnaires on
Table 2:Physicochemical parameters of the water samples and WHO water quality standard

\begin{tabular}{|c|c|c|c|}
\hline Parameters & $\begin{array}{c}\text { Sample } \\
\text { A }\end{array}$ & $\begin{array}{c}\text { Sample } \\
\text { B }\end{array}$ & $\begin{array}{c}\text { WHO Highest } \\
\text { Desirable Level } \\
\text { (HDL) }\end{array}$ \\
\hline$\overline{\text { Colour (hazen unit) }}$ & 30 & 20 & 5 Hazen unit \\
\hline $\mathrm{pH}$ & 5.1 & 6.4 & $7.0-8.5$ \\
\hline Total hardness $\left(\mathrm{mgL}^{-1}\right)$ & 120 & 115 & $100 \mathrm{mgL}^{-1}$ \\
\hline Total suspended solids $\left(\mathrm{mgL}^{-1}\right)$ & 230 & 209 & $200 \mathrm{mgL}^{-1}$ \\
\hline Dissolved oxygen $\left(\mathrm{mgL}^{-1}\right)$ & 2.2 & 2.5 & $3.0 \mathrm{mgL}^{-1}$ \\
\hline $\mathrm{BOD}\left(\mathrm{mgL}^{-1}\right)$ & 520 & 513 & $500 \mathrm{mgL}^{-1}$ \\
\hline Fecal coliform & $2.3 \times 10^{2}$ & 120 & $100 \mathrm{mgL}^{-1}$ \\
\hline Chlorine $\left(\mathrm{mgL}^{-1}\right)$ & 225 & 218 & $200 \mathrm{mgL}^{-1}$ \\
\hline Calcium $\left(\mathrm{mgL}^{-1}\right)$ & 90 & 82 & $75 \mathrm{mgL}^{-1}$ \\
\hline $\operatorname{Iron}\left(\mathrm{mgL}^{-1}\right)$ & 0.5 & 0.3 & $0.1 \mathrm{mgL}^{-1}$ \\
\hline Magnesium $\left(\mathrm{mgL}^{-1}\right)$ & 180 & 165 & $150 \mathrm{mgL}^{-1}$ \\
\hline Nitrate $\left(\mathrm{mgL}^{-1}\right)$ & 20 & 14 & $10 \mathrm{mgL}^{-1}$ \\
\hline $\operatorname{COD}\left(\mathrm{mgL}^{-1}\right)$ & 360 & 245 & $200 \mathrm{mgL}^{-1}$ \\
\hline Total dissolved solids $\left(\mathrm{mgL}^{-1}\right)$ & 580 & 540 & $500 \mathrm{mgL}^{-1}$ \\
\hline
\end{tabular}

the variations in the sources of water for domestic purposes in the study area. During rainy season, rain water accounts highest with 160 respondents because of its availability in the rainy season. This is followed by hand-dug wells with 144 respondents; 30 indicated streams as their source of water during rainy season. Tankers had 4 respondents and bore hole had 1 . Furthermore, during dry season, stream/rivers indicated highest with 159 respondents which show streams to be the major source of water for domestic purpose during dry season. This is followed by hand-dug wells with 140 respondents. About 32 respondents indicated boreholes to be their source of water during this season. Tankers had 20 respondents. About 10 respondents indicated springs as their source of water during dry season.

Respondents identified reasons why people dump refuse into stream: Field observation and questionnaires revealed that majority of the people dump their refuse into run off channel that leads to the stream/rivers while others dump their own into river/stream during dry season. About 29.9\% responded that lack of enlightenment is the major cause of dumping refuse into the stream. About $23 \%$ of the respondent indicated that there is no particular place set aside for waste disposal by the government. About $17.8 \%$ of the respondent indicated that nearness to the stream is the reason why they dispose refuse into them while $13.3 \%$ of the respondent said that people dump refuse into stream because of convenience. These responses are illustrated in Fig. 4 and 5(Akaninwor et al., 2007).

Physicochemical parameters compared with WHO standard: From Table 2, the physicochemical parameters (colour, $\mathrm{pH}$, total dissolved solids, total suspended solids, chemical oxygen demand, biochemical oxygen demand, coliform, nitrates, chloride, calcium, magnesium and dissolved oxygen) were each seen to be above the recommended WHO standard. This means the stream (Okpe stream) is heavily polluted. The concentration of 


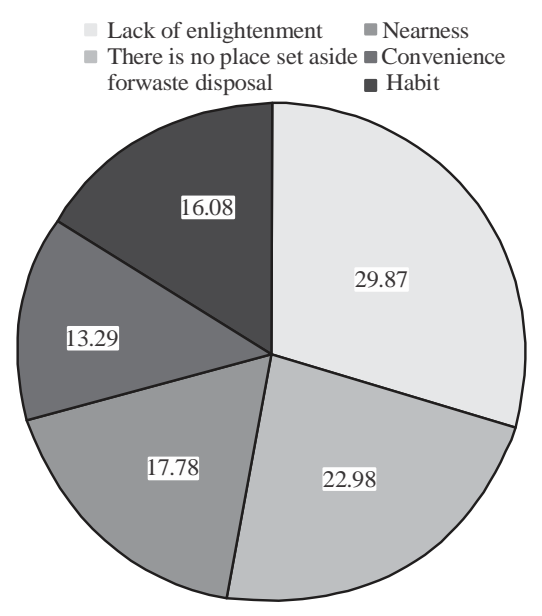

Fig. 5: Respondents identified reasons why people dump refuse into stream

the pollutants were seen to decrease with distance (that is from point $A$ at $1.2 \mathrm{~m}$ to point $B$ which is at $2.5 \mathrm{~m}$ from the refuse dump).

Health implication of the contaminated water: Polluted surface waters cause a number of diseases such as diarrhoea and dysentery, hepatitis, typhoid, cholera. Diarrhoea and dysentery are similar disease. The only difference is that in dysentery, there is blood in the stool while there is none in the case of the diarrhoea, World Health Organization (WHO., 2005). When there is a case of diarrhoea, the patient passes out more water than is normal. This leads to under nutrition and death in severe situations. Where one suffers from acute diarrhoea at a tender age, there is the possibility that the patient might have growth and development retarded for sometime. Pathologically diarrhoea and dysentery have their causes in E. coli which occur where there is biological pollution in water. Typhoid is a disease of the intestines which is caused by the typhoid germ salmonella typhoid. The germ persists in stool longer than in the urine. The consumption of water contaminated by feaces is one of the ways through which it is spread. The disease carries high fever, headaches, cough, belly ache, constipation and loss of appetite.

Cholera is similar to diarrhoea and dysentery. It has the ability to spread rapidly in sewerage contaminated water supplies. It also occurs where there is reasonable fecal contamination of water being consumed.

Domestic health implications: Water borne enteric viruses threaten both human and animal health. These pathogens are host specific and cause a wide range of diseases and symptoms in humans. While considerable research has documented the risk of enteric viruses to human health from contact with contaminated surface water, the current bacterial indicator-based methods for evaluation of water quality are often ineffectual proxies for pathogenic viruses (Oliveira et al., 2006). Enteric virus may be present naturally in aquatic environments or more commonly are introduced through human activities such as leaking sewage and septic systems, urban runoff, agriculture runoff and in the case of estuarine and marine water, sewage outfall and vessel wastewater discharge. These viruses can be transported in the environment through surface water, rivers, aerosols emitted from sewage treatment plants insufficient treated water, drinking water and private wells that receive treated or untreated wastewater either directly or indirectly (Bitton, 1980). Toxic substances can cause cancer, birth defects and other illnesses. The severity of the effect usually depends on the dose, defined as the weight of the contaminated consumed per day divided by body weight. In Ejigbo, health problems from chronic toxicity are more difficult to diagnose because they often remain latent for years. Once such problems become manifest, they may be difficult or impossible to treat (Obinna, 2009). This complication makes chronic toxicity from organic pollutants the major concern of investigating surface water quality. Humans ingest nitrates from food and water. Once nitrate enters the body of humans older than 6 months, it is steadily absorbed from the digestive tract and excreted in the urine. Healthy human adults can consume fairly large amounts of nitrate with little harmful effect. In Eha-Alumona infants under 6 months, however were found susceptible to nitrate poisoning because their undeveloped tracts possess bacteria that covert nitrate in to nitrite which is toxic. When nitrite enters the bloodstream, it reacts with oxygen carrying haemoglobin and forms a compound called methemoglobin. This compound reduces the blood's ability to carry oxygen. As oxygen levels decreases infants may show signs of suffocation, a condition called methemoglobinnema. The most conspicuous symptoms of methemoglobinnema is bluish skin, most noticeably around the eyes and mouth. Apart from the health risk posed by surface water contamination, many household health related problems have been observed in Eha-Alumona urban, ranging from contaminated water been used for cooking, laundry, washing of dishes, bathing and others (Singhal and Pandey, 2001).

Health implications on livestock: Because bacteria in the rumen convert nitrate to oxygen-seeking nitrite, nitrite poisoning occurs most often in ruminant animals such as cattle and sheep. Monogastric animals such as swine and chickens have no rumen, thus, they rapidly eliminate nitrite in their urine. Young monogastric animals, however are similar to human infant in that they are highly susceptible nitrite poisoning until their digestive system developed. Although, horses are monogastric, their large cerium acts as a rumen, converting nitrate to nitrite. Through over fertilization, 
many plants accumulate nitrate levels that can harm livestock through, surface water intake. In water, however, nitrate rarely proves harmful. High nitrate water, generally, threatens animal only when it is added to high nitrate concentrations already present in ingested feed. Symptoms include mucous membranes, vomiting and abortions. Dairy cows, however can have reduced milk production without showing any symptoms (Sweeting, 1994).

\section{CONCLUSION}

The quality of surface waters in Eha-Alumona and environs has been impaired. This poses a threat to the inhabitant. The pollutants which led to impairment of the quality of surface waters in the study area were probably from agricultural farmlands along the banks of the surface waters, construction of latrine along the banks by the inhabitants, washing of breadfruit, oil palm nuts, fermented cassava and indiscriminate disposal of domestic wastes into the surface waters. In addition, natural factors such as sediments from dissolution of rock minerals during weathering, runoff generated from rainfall and decomposition of leaves by micro organisms may also have contributed to observed pollutant loads in the area. The detrimental impact of this impairment of surface waters affects not only the physical, economical and social wellbeing of the people but also have fatal consequence on the aquatic organisms. A continued increase in the pollution level of the surface waters will ultimately prove fatal to human life in the study area.

\section{RECOMMENDATIONS} work:

The following are recommended from this research

Re-orientation of the people: The people of Eha-Alumona urban area should be encouraged to desist from improper disposal of waste, to collect their waste frequently (at least every week) and to establish a refuse disposal monitoring team within Eha-Alumona and environs.

Sorting of waste: The sorting of wastes into different types and the collection of the sorted wastes into different containers are recommended. The sorting of wastes by classification will bring about possible recycling and treatment and proper disposal into the land or water environment. When wastes are sorted and recycled or treated, those that are unfit to be disposed in the surface water may be properly disposed in the land. This makes the surface water body free from such contamination.

Treatment of contaminated surface water: The treatment of contaminated surface water and also the reduction of the volume of contaminants which flow from households and industries into rivers. When the volume of contaminated water which flows into the river is reduced, the extent of contamination on the rivers will equally be minimized.

Reduced use of contaminants by the people: The use of fertilizers, pesticides and herbicides by the people should be avoided on farmlands close to water sources in the area. Alternatively, plants (trees) should be grown on the river bank to serve as buffer zones on the riverbank to prevent contaminant runoff from flowing into the river from farmlands.

Close monitoring: Monitoring at regular intervals and periods to watch out against possible discards of wastes into the streams is essential. When this is done, the cause of contamination could be traced and solutions proffered.

\section{REFERENCES}

AOAC., 2005. Standard Official Methods of Analysis. 15th Edn., Association of Official Analytical Chemists, Washington, DC., USA.,.

Adejemilua, F., 2007. Latitude of Environmental and Resource Management. Hebn Publishers Plc, Ibadan, Nigeria,.

Akaninwor, J.O., E.O. Anosike and O. Egwim, 2007. Effect of Indomie industrial effluent discharge on microbial properties of new Calabar River. Sci. Res. Essays, 2: 1-5.

Arvill, 1967. The Paradise and Hell in the Oil Producing Niger Delta. The Vanguard Group, Valley Forge, Pennsylvania, USA., Pages: 84.

Benka-Coker, M.O. and O.O. Ojior, 1995. Effect of slaughterhouse wastes on the water quality of Ikpoba River, Nigeria. Biosci. Technol., 52: 5-12.

Bitton, 1980. In Focus: Water-Local Level Management. International Development Research Centre (IDRC), Ottawa, Canada,.

Egwari, L. and O.O. Aboaba, 2002. Environmental impact on the bacteriological quality of domestic water supplies in Lagos, Nigeria. Rev. Saude Publ., 36: 513-520.

Kinnersley, D., 1994. Coming Clean: The Politics of Water and the Environment. Penguin Books, London, UK., ISBN-13:978-0140154481, Pages: 256.

Nwachukwu, E. and T.V. Otokunefor, 2003. Seasonal changes in the sanitary quality of surface water in the rural community of River State, Nigeria. Niger. J. Microbiol., 17: $110-114$.

Obinna, A.C., 2009. Paleogeographic History of Nigeria from Albian Times. In: Geology of Nigeria, Kogbe, C.A. (Ed.). Elizabethan Publishers, Lagos, Nigeria, pp: 237-252. 
Odokuma, L.O. and G.C. Okpokwasili, 2004. Seasonal ecology of hydrocarbon-utilizing microbes in the surface waters of a river. Environ. Monit. Assess., 27: 175-191.

Oliveira, M.F.D., G. Corcao and S.T.V.D. Sand, 2006. An evaluation of transient bacterial population in a polluted bathing site in Porto Alegre-Brazil. Biociencias Porto Alegre, 14: 136-143.

Singhal, S. and S. Pandey, 2001. Solid waste management in India: Status and future directions. TERI Inform. Monit. Environ. Sci., 6: 1-4.
Sweeting, R.A., 1994. River Pollution. In: Rivers Handbook, Petts, G. and P. Calow (Eds.). Blackwell's, Australia, pp: 23-32.

Ubalua, A.O. and O.U. Ezeronye, 2005. Nutrients and selected physico-chemical analysis in the Aba river surface waters, Abia State, Nigeria. Environ. Ecol., 23: $141-144$.

WHO., 2005. Guidelines for Drinking Water, Health Criteria and other Supporting Information. Vol. 2, World Health Organization, Geneva, Switzerland,. 